\title{
Pathological changes in the rabbit ileal loop model caused by Campylobacter jejuni from human colitis
}

\author{
P. H. EVEREST§, H. GOOSSENS*, P. SIBBONS $\uparrow$, D. R. LLOYD $\ddagger$ S. KNUTTON $\ddagger$, R. LEECE, \\ J. M. KETLEY and P. H. WILLIAMS"
}

\begin{abstract}
Department of Genetics, University of Leicester, Leicester LE1 7RH, "WHO Collaborating Centre for Enteric Campylobacter, Department of Microbiology. St Pieters Hospital, B-1000 Brussels, Belgium, †Department of Paediatric Surgery, Institute of Child Health, Great Ormond Street, London WC1N 1 EH and $\ddagger$ Institute of Child Health, University of Birmingham, Birmingham B16 $8 E T$
\end{abstract}

\begin{abstract}
Summary. Four strains of Campylobacter jejuni isolated from children with inflammatory diarrhoea were assayed in the rabbit ileal loop model of infectious diarrhoea. All caused inflammatory reactions with severe macroscopic and microscopic damage in infected rabbit ileal tissue similar to that observed in the patients by endoscopy and histological analysis of colonic biopsies. Haemoglobin and other proteins were observed in loop fluids, consistent with leakage of serum from damaged mucosa. Loop fluids also contained significant bicarbonate concentrations, indicative of an active secretory component similar to that in control loops inoculated with cholera toxin. However, although three of the four clinical strains produced small amounts of a protein immunologically related to cholera toxin in vitro, none such was detected in either tissues or fluids of infected ileal loops. We propose instead that host-derived mediators of secretion may be important in pathogenesis. A mutant strain of $C$. jejuni with impaired motility, obtained from the National Collection of Type Cultures, did not induce tissue damage or fluid secretion in rabbit ileal loops.
\end{abstract}

\section{Introduction}

Campylobacter jejuni is a major cause of enterocolitis among children and young adults in developed and developing countries. ${ }^{1,2}$ Symptoms range in severity from acute watery diarrhoea to those of an inflammatory disease that may be associated with tissue invasion, ${ }^{3-5}$ and occasional bacteraemia. ${ }^{6}$ Several animal models that mimic the histopathology of human disease have been developed, ${ }^{7-9}$ but the animals used have generally been large and expensive, and no simple small mammal model for the pathogenesis of campylobacter enterocolitis exists that does not demand prior treatment or surgical procedures. ${ }^{10-13}$ The "removable intestinal tie adult rabbit diarrhoea" (RITARD) procedure ${ }^{14,15}$ has been used successfully for the analysis of histological changes and immune responses in $C$. jejuni infection, ${ }^{16}$ but secreted fluids are not available for analysis in this system, in which ligation of the ileum is only temporary. The rabbit ileal loop test (RILT) has also been used for various infectious diarrhoeal diseases, ${ }^{17-21}$ including a preliminary study of infection with $C$. jejuni. ${ }^{22}$ This

Received 25 Aug. 1992; accepted 13 Oct. 1992.

Present addresses: §Department of Biochemistry, Imperial College, London SW7 2BB; *Laboratorium voor Microbiologie, UZ Antwerpen, B-2650 Edegem (Antwerpen); †Department of Pathology, Alderhay Children's Hospital, Liverpool L7 7DG.

"Correspondence should be sent to Dr P. H. Williams. technique has the advantage that both tissues and secreted fluids can be collected for histological and biochemical examination. The purpose of the work reported in this paper was to analyse the pathological effects of $C$. jejuni isolates from human colitis in the RILT, with a view to assessing its effectiveness as a model for the study of human disease.

\section{Materials and methods}

\section{Bacteria and culture conditions}

C. jejuni strains L115, C119, O81 and P71 used in this study have been described previously. ${ }^{5}$ They were isolated from the stools of children with inflammatory diarrhoea during bacteriological screening at the Department of Microbiology, St Pieters University Hospital, Brussels. Data from recto-colonoscopy, performed routinely to exclude ulcerative colitis and Crohn's disease, and histological analysis of colonic biopsies are shown in table I. All strains were motile as judged by phase contrast light microscopy, and all showed cytotoxic activity against cultured Chinese hamster ovary (CHO) cells. All except strain P71 produced cholera-like toxin, as previously determined by elongation of $\mathrm{CHO}$ cells, ${ }^{5}$ and confirmed here by monosialganglioside GM1-enzyme linked immunosorbent assays (GM1-ELISA) ${ }^{23}$ Mutant $C$. jejuni strain NCTC 12189 was also used; this strain has 
Table I. Histology in RILT compared with endoscopy and histology in man

\begin{tabular}{|c|c|c|c|}
\hline \multirow{2}{*}{$\begin{array}{l}\text { Inoculated } \\
\text { strain or } \\
\text { compound }\end{array}$} & \multicolumn{2}{|c|}{ Lesions in man } & \multirow{2}{*}{ Histology in RILT } \\
\hline & Endoscopy & Histology & \\
\hline $\mathrm{L} 115\left(\mathrm{ENT}^{+} \mathrm{CYT}^{+}\right)$ & $\begin{array}{l}\text { Large nodular ulceration, severe } \\
\text { oedema, hyperaemia, mucus and } \\
\text { pus }\end{array}$ & $\begin{array}{l}\text { Tissue oedema, cryptitis, marked } \\
\text { PMNL infiltration }\end{array}$ & $\begin{array}{l}\text { Blood-stained mucosa, flattened } \\
\text { villi, cell damage, moderate } \\
\text { PMNL infiltration, submucosal } \\
\text { bleeding }\end{array}$ \\
\hline $\mathrm{C} 119\left(\mathrm{ENT}^{+} \mathrm{CYT}^{+}\right)$ & $\begin{array}{l}\text { Large nodular ulceration, severe } \\
\text { oedema, hyperaemia, mucus and } \\
\text { pus }\end{array}$ & $\begin{array}{l}\text { Tissue oedema, cryptitis, marked } \\
\text { PMNL infiltration }\end{array}$ & $\begin{array}{l}\text { Blood-stained mucosa, } \\
\text { "Christmas tree" villi, } \\
\text { moderate PMNL infiltration, } \\
\text { submucosal oedema and } \\
\text { bleeding }\end{array}$ \\
\hline $\mathrm{O} 81\left(\mathrm{ENT}^{+} \mathrm{CYT}^{+}\right)$ & $\begin{array}{l}\text { Micronodular ulceration, } \\
\text { moderate oedema, hyperaemia }\end{array}$ & $\begin{array}{l}\text { Tissue oedema, marked PMNL } \\
\text { infiltration }\end{array}$ & $\begin{array}{l}\text { Haemorrhagic mucosa, damaged } \\
\text { villi, marked PMNL infiltration, } \\
\text { submucosal oedema and } \\
\text { bleeding }\end{array}$ \\
\hline $\mathrm{P} 71^{*}\left(\mathrm{ENT}^{-} \mathrm{CYT}^{+}\right)$ & Moderate hyperaemia & Moderate PMNL infiltration & $\begin{array}{l}\text { Blood-stained mucosa, flattened } \\
\text { villi, light PMNL infiltration, } \\
\text { red cells in submucosa }\end{array}$ \\
\hline NCTC 12189 & Not applicable & Not applicable & Villi and submucosa normal \\
\hline $\mathrm{CT}$ & Not applicable & Not applicable & $\begin{array}{l}\text { Some "Christmas tree" villi, } \\
\text { submucosa normal }\end{array}$ \\
\hline PBS & Not applicable & Not applicable & Villi and submucosa normal \\
\hline
\end{tabular}

ENT, enterotoxin; CYT, cytotoxin; CT, cholera toxin.

PMNL, polymorphonuclear leucocytes.

${ }^{*}$ Loops inoculated with P71, which showed no fluid, also showed no histological damage.

reduced motility, despite retaining intact flagella, and is unable to colonise the intestinal tract of infant mice. ${ }^{24}$ Bacteria were grown micro-aerophilically in Mueller-Hinton (MH) broth overnight at $42^{\circ} \mathrm{C},{ }^{5}$ harvested by low speed centrifugation, and resuspended at $c .10^{8}$ bacteria $/ \mathrm{ml}$ in phosphate-buffered saline (PBS) for injection into rabbit ileal loops.

\section{Rabbit ileal loop tests}

Surgical procedures on 7-9 week-old specific pathogen-free New Zealand White rabbits $(<2 \mathrm{~kg})$ were performed under licence by standard techniques. ${ }^{17,18}$ Briefly, laparotomy was performed on anaesthetised animals from the lower liver margin to the level of the iliac fossa. The distal ileum and the ileo-caecal junction were elevated, and $5-\mathrm{cm}$ long sections of ileum, $10 \mathrm{~cm}$ apart, close to the ileo-caecal junction, were tied with silk thread. Two animals were used for each bacterial strain, each animal having two test loops and two control loops. Test loops were inoculated with $0.5-\mathrm{ml}$ volumes of bacterial suspensions in phosphate-buffered saline (PBS). Positive control loops were inoculated with $1 \mu \mathrm{g}$ of cholera toxin (CT) in $0.5 \mathrm{ml}$ of PBS; negative control loops received $0.5 \mathrm{ml}$ of PBS alone. Loops were replaced in the peritoneal cavity in their original positions, and the peritoneum was closed. Animals were again anaesthetised $18 \mathrm{~h}$ after inoculation, and laparotomy was performed as before. Loops were removed and weighed, and loop fluids were stored in sterile containers. Loop tissue was washed in PBS and fixed in formaldehyde $3 \%$; thin sections were stained with haematoxylin and eosin, and examined under bright field illumination with a Zeiss Axiophot microscope. Homogenised tissue extracts were tested for the presence of cholera-like enterotoxin by GM1-ELISA (see below).

\section{Fluid analysis}

Loop fluids were centrifuged to remove cellular components and assayed for bicarbonate (mM), $\mathrm{pH}$ and haemoglobin $(\mathrm{mg} / \mathrm{ml})$ with a Howe ABL-2 acidbase laboratory analyser (Radiometer, Copenhagen), and for total protein $(\mathrm{mg} / \mathrm{ml})$ by the method of Bradford. ${ }^{25}$ Fluids were also examined by bright field microscopy for the presence of red and white blood cells, and tested for cholera-like enterotoxin by GM1ELISA (see below).

\section{Microbiological analysis}

Loop fluids were plated for viable counts of $C$. jejuni on MH agar essentially as described by Miles $e t$ al. ${ }^{26}$ Loop tissue samples $(c .0 .5 \mathrm{~g})$ were washed with PBS, homogenised in $0.5 \mathrm{ml}$ of PBS with a pestle and mortar, and plated for viable counts on $\mathrm{MH}$ agar. Blood samples taken post mortem were lysed with deoxycholate (Sigma) $0.5 \%$ and plated for viable counts on MH agar. Peritoneal fluids and homogenised samples $(c .0 .5 \mathrm{~g})$ of liver and gall bladder tissue taken post mortem were cultured on MH agar for $C$. jejuni. Bacterial serum sensitivity was determined as described by Taylor. ${ }^{27}$ Briefly, $(2-5) \times 10^{6}$ viable bacteria in gelatin-veronal buffer containing 

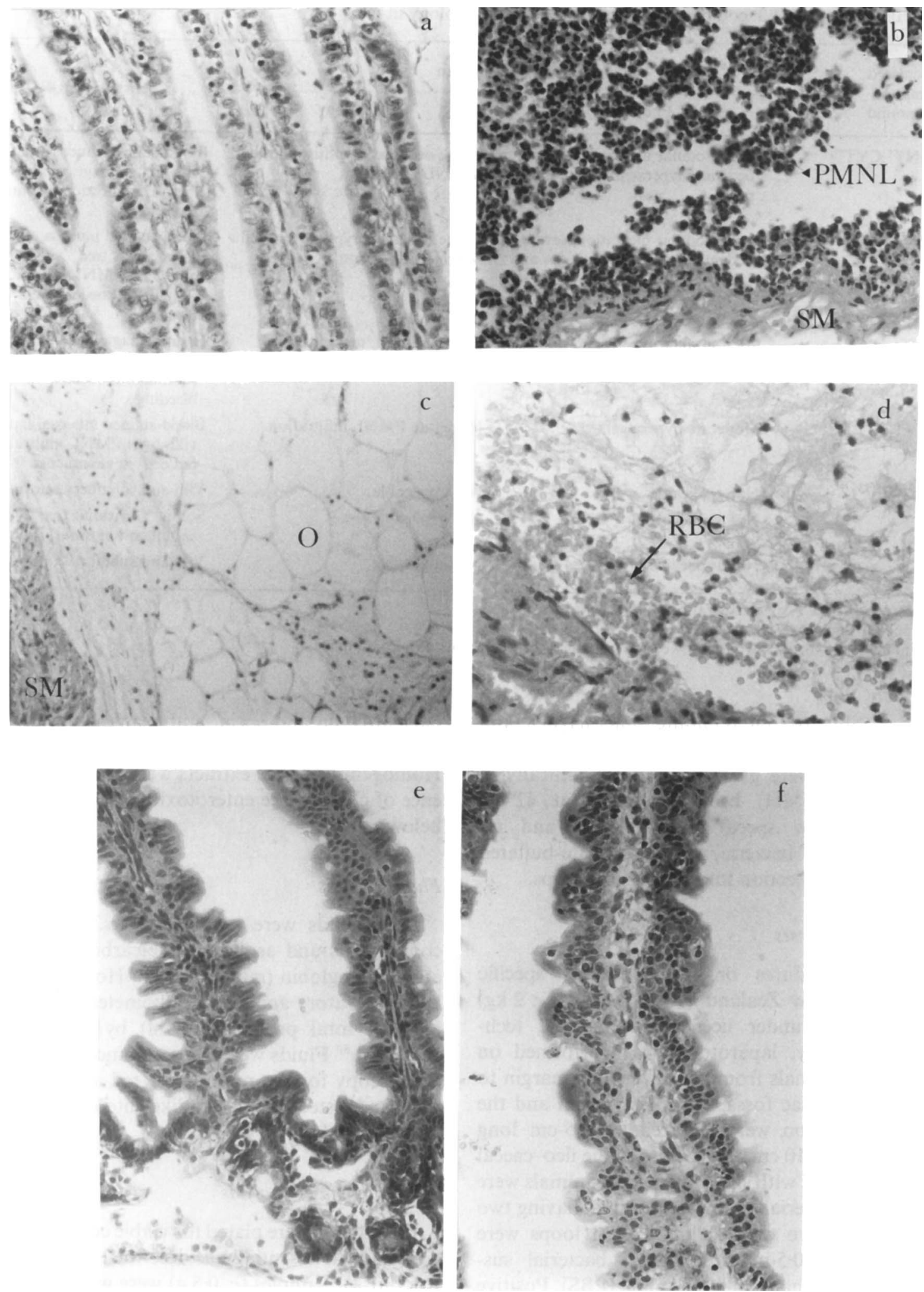

Figure. Histology of rabbit ileal loop tissue after infection with inflammatory strains of $C$. jejuni. Panels show representative bright field micrographs $(\times 40)$ of thin sections stained with haematoxylin and eosin. Panels show (a) untreated ileal villi; or ileal loop tissue infected with strain O81 highlighting (b) white cell infiltrate with predominant PMNL response, (c) severe oedema, and (d) submucosal bleeding. Panels (e) and (f) show "Christmas-tree" villi in ileal loop tissue inoculated with strain C119 and CT, respectively. O, oedema; PMNL, polymorphonuclear leucocytes; RBC, red blood cells; SM, submucosa.

calcium and magnesium were incubated at $37^{\circ} \mathrm{C}$ in a 1 in 25 dilution of human or rabbit serum. Samples taken at intervals over a period of $3 \mathrm{~h}$ were subjected to viable counts on $\mathrm{MH}$ agar.

\section{GM1-ELISA for cholera-like enterotoxin}

GM1-ELISA was performed essentially as previously described ${ }^{23}$ Wells of 96-well microtitration 
Table II. Fluid production and analysis

\begin{tabular}{|c|c|c|c|c|c|c|}
\hline \multirow{2}{*}{$\begin{array}{l}\text { Inoculated } \\
\text { strain or } \\
\text { compound }\end{array}$} & \multirow{2}{*}{$\begin{array}{c}\text { Positive } \\
\text { loops } \\
\text { (/total } \\
\text { inoculated) }\end{array}$} & \multirow{2}{*}{$\begin{array}{c}\text { Mean } \\
\text { fluid } \\
\text { volume, } \\
\text { ml (range) }\end{array}$} & \multirow[t]{2}{*}{$\begin{array}{l}\text { Mean } \\
\text { bicarbonate } \\
\text { mM (range) }\end{array}$} & \multirow[t]{2}{*}{$\mathrm{pH}$} & \multicolumn{2}{|c|}{$\begin{array}{l}\text { Protein content, } \\
\mathrm{mg} / \mathrm{ml} \text { (range) }\end{array}$} \\
\hline & & & & & total & haemoglobin \\
\hline L115 & $4 / 4$ & $\begin{array}{c}3 \cdot 0 \\
(1-8)\end{array}$ & $\begin{array}{c}48 \cdot 3 \\
(19 \cdot 7-62 \cdot 8)\end{array}$ & $\begin{array}{c}7 \cdot 83 \\
(7 \cdot 47-8 \cdot 11)\end{array}$ & $\begin{array}{l}2 \cdot 0 \\
\ldots\end{array}$ & $\begin{array}{l}0 \cdot 10 \\
(0-0 \cdot 2)\end{array}$ \\
\hline $\mathrm{C} 119$ & $4 / 4$ & $\begin{array}{c}8 \cdot 2 \\
(1 \cdot 5-18)\end{array}$ & $\begin{array}{c}66 \cdot 5 \\
(15 \cdot 6-93 \cdot 8)\end{array}$ & $\begin{array}{c}7.92 \\
(7 \cdot 53-8 \cdot 14)\end{array}$ & $\begin{array}{l}2 \cdot 0 \\
\ldots\end{array}$ & $\begin{array}{l}0.06 \\
(0-0 \cdot 2)\end{array}$ \\
\hline O81 & $4 / 4^{*}$ & $\begin{array}{c}2.0 \\
(1.5-3 \cdot 5)\end{array}$ & $\begin{array}{c}30 \cdot 5 \\
(17 \cdot 7-43 \cdot 3)\end{array}$ & $\begin{array}{c}7 \cdot 65 \\
(7 \cdot 52-7 \cdot 78)\end{array}$ & $\begin{array}{c}2 \cdot 5 \\
(2 \cdot 0-5 \cdot 0)\end{array}$ & $\begin{array}{c}0 \cdot 35 \\
(0 \cdot 2-0 \cdot 5)\end{array}$ \\
\hline P71 & $2 / 4^{*}$ & 5.0 & $54 \cdot 1$ & 8.08 & 5.0 & 0.60 \\
\hline NCTC 12189 & $0 / 4$ & 0 & ND & ND & ND & ND \\
\hline $\mathrm{CT}$ & $10 / 10$ & $13 \cdot 7$ & 86.3 & 8.05 & $0 \cdot 34$ & $<0.01$ \\
\hline PBS & $0 / 10$ & $\begin{array}{c}(4-25) \\
0\end{array}$ & $\begin{array}{c}(62 \cdot 1-113 \cdot 6) \\
6 \cdot 5 \dagger\end{array}$ & $\begin{array}{c}(7 \cdot 64-8.26) \\
7.27 \dagger\end{array}$ & $\begin{array}{c}(0-0 \cdot 4) \\
0 \dagger\end{array}$ & $\begin{array}{l}(0-0.02) \\
0 \dagger\end{array}$ \\
\hline
\end{tabular}

Values are averages for loops from which fluid was recovered.

ND, not done, no fluid secretion.

*Fluid was lost due to perforation of one positive loop inoculated with strain O81 and one inoculated with P71.

†Values for PBS before injection into loops.

plates were coated with GM1 (Sigma; $150 \mathrm{ng} /$ well) and exposed to samples to be tested for the presence of cholera-like enterotoxin. Plates were incubated with rabbit antiserum against CT B subunit (Sigma), and the presence of primary antiserum was detected by incubation with goat anti-rabbit antibodies conjugated with horseradish peroxidase.

\section{Results}

\section{Histological effects of C. jejuni infection}

Clear similarities were observed between the severity of histopathological changes in colitis patients and in ligated rabbit ileal loops infected with $C$. jejuni strains isolated from those patients (table I). Some loops showed macroscopic damage with obvious mucosal haemorrhage; one loop inoculated with strain 081 and one loop inoculated with strain P71 were perforated. Tissue sections typically indicated inflammatory reactions comprising predominantly polymorphonuclear leucocyte (PMNL) infiltrate with macrophages (figure, b), tissue oedema (figure, c), and cell damage and submucosal bleeding (figure, d). In intestinal tissue infected with strain C119, some of the villi resembled Christmas trees (figure, e), a response identical with that observed (figure, $f$ ) and previously reported $^{27}$ for CT-mediated fluid secretion. However, although strain $\mathrm{C} 119$ produced small amounts of cholera-like enterotoxin, as determined both by $\mathrm{CHO}$ cell elongation ${ }^{5}$ and by GM1-ELISA of $\mathrm{MH}$ broth culture supernates $(0.003 \mu \mathrm{g} / \mathrm{ml})$, no activity was detected by GM1-ELISA in homogenised tissue samples infected with strain C119 $(<0.0001 \mu \mathrm{g} / \mathrm{ml})$. Similar results were obtained for the two enterotoxinproducing inflammatory strains, L115 and O81, which did not elicit Christmas tree-like villous morphology. However, the possibility that toxin bound to or inside cells was not released by tissue homogenisation cannot be ruled out, although CT was detected by GM1ELISA in CT-treated loop tissue $(0 \cdot 02-0 \cdot 14 \mu \mathrm{g} / \mathrm{ml})$. Strain NCTC 12189 elicited no histological changes in the rabbit mucosa.

\section{Loop fluid analysis}

All four inflammatory isolates stimulated fluid accumulation in infected loops, but fluid volumes were lower than those in loops inoculated with CT. For strains L115 and C119, all four test loops contained fluid. One of the four loops infected with strain 081 had ruptured, but fluid was recovered from the other three loops. Strain P71, which was associated with less severe symptoms in patients (table I), caused fluid accumulation in only two loops, one in each test animal, but fluid was lost by rupture of one of the loops. Fluids from infected loops did not have the appearance of frank blood, but in all cases macroscopic or microscopic blood was observed, and PMNLs were present, suggesting tissue damage. Consistent with this, haemoglobin and other protein concentrations were higher in loop fluids induced by C. jejuni infection than in those from CT-treated loops, in which fluid was induced solely by an active secretory process (table II). Fluids induced by bacterial infection contained generally higher bicarbonate concentrations than normal rabbit blood (16.2$31.8 \mathrm{~mm}$ ); generally, higher fluid bicarbonate concentrations correlated with higher $\mathrm{pH}$ (table II). High bicarbonate concentrations were also observed in fluids stimulated by $\mathrm{CT}$ treatment. Cholera-like enterotoxin was not detected by GM1-ELISA in loop fluids induced by inflammatory strains that produced small amounts of toxin in vitro $(<0.0001 \mu \mathrm{g} / \mathrm{ml})$, although the method detected CT in the fluids of CTtreated loops $(0.04-0.5 \mu \mathrm{g} / \mathrm{ml})$. No fluid accumulation was observed with strain NCTC 12189. 
Table III. Microbiological analysis

\begin{tabular}{|c|c|c|c|c|c|}
\hline \multirow{2}{*}{ Strain } & \multirow[b]{2}{*}{ fluid } & \multicolumn{2}{|c|}{ Viable counts ${ }^{*}$ in } & \multicolumn{2}{|c|}{ Serum sensitivity $\dagger$ of } \\
\hline & & tissue & blood & $\begin{array}{l}\text { loop } \\
\text { inoculum }\end{array}$ & $\begin{array}{l}\text { blood } \\
\text { isolate }\end{array}$ \\
\hline L115 & $1.5 \times 10^{11}$ & $2.7 \times 10^{11}$ & 10 & $0 \cdot 3$ & $2 \cdot 7$ \\
\hline C119 & $1.1 \times 10^{11}$ & $2.9 \times 10^{10}$ & 11 & 1.0 & $1 \cdot 3$ \\
\hline O81 & $3.9 \times 10^{10}$ & $4.9 \times 10^{10}$ & 12 & 9.8 & $4 \cdot 0$ \\
\hline P71 & $6.0 \times 10^{7}$ & $4.0 \times 10^{7}$ & 12 & 4.0 & 0.8 \\
\hline NCTC 12189 & ND & $8 \cdot 2 \times 10^{7}$ & 0 & 5.7 & 4.9 \\
\hline
\end{tabular}

ND, not done, no fluid secretion.

${ }^{*} \mathrm{cfu} / \mathrm{ml}$; values for tissues $(0.5 \mathrm{~g}$ of homogenised tissue in $0.5 \mathrm{ml}$ of PBS) include attached and invading bacteria.

†Percentage survival after incubation for $3 \mathrm{~h}$ in human serum (identical data were obtained with rabbit serum).

\section{Microbiological analysis}

Extensive mucosal colonisation by strains L115, $\mathrm{C} 119$ and $\mathrm{O} 81$ was indicated by high viable bacterial counts in samples of infected loop tissue and, consequently, in loop fluids (table III). Strain P71 colonised to a lesser extent, but nevertheless caused significant tissue damage. Viable bacterial counts of strain NCTC 12189 in loop tissue were similar to those of P71, but colonisation with the mutant strain was not associated with tissue damage in this model. Post-mortem blood cultures were positive for all strains except NCTC 12189 , suggesting true bacteraemia resulting from tissue damage, rather than operational trauma. However, viable counts were very low (10-12 bacteria/ml of blood) presumably because strains were sensitive to the bactericidal action of serum, both before and after loop inoculation (table III). The peritoneal fluids of all animals infected with the four inflammatory strains of C. jejuni were culture positive, as were the liver and gall bladder of rabbits infected with strain L115 (data not shown). This probably reflects seeding from the bloodstream.

\section{Discussion}

Studies with the RITARD technique indicate that the rabbit ileum is a good model for histopathological changes associated with campylobacter enterocolitis in man. ${ }^{16}$ The particular advantage of the RITARD method is that infection can be initiated by the oral route, the usual route of natural infection in man; its main disadvantage is that it is not possible to assess the nature of fluid secretion in conjunction with tissue damage. The RILT, on the other hand, does not allow oral infection but has the advantage that the effects of variability between animals can be minimised by the inclusion of control loops alongside test loops. This also reduces the number of animals needed. Important, too, is the fact that intestinal fluids can be recovered for analysis.

Strains of $C$. jejuni isolated from cases of human colitis differed somewhat in their effects in this model.
Those that caused more severe disease in man, as judged by endoscopy and histological examination, caused greater histological damage in rabbit ileal loops, but all four produced shortened villi, white cell infiltration and bleeding into the mucosa, observations consistent with the inflammatory type of illness seen in man, in which faecal samples typically contain blood and PMNLs. ${ }^{2}$ Bacteraemia was observed with all four clinical isolates in this study. Campylobacter bacteraemia in man is not as rare as was previously suspected, particularly among hospitalised patients. ${ }^{28}$ However, since most $C$. jejuni strains are sensitive to the bactericidal action of normal serum, ${ }^{29}$ isolation of organisms from blood cultures presumably reflects their presence within circulating white cells.

Biochemical analysis of loop fluids induced by $C$. jejuni infection is consistent with leakage of serum proteins and blood cells into the gut lumen through damaged epithelial and endothelial tissues, as reported for other organisms. ${ }^{30}$ It is tempting to speculate that cytotoxins are the cause of this, since all four strains produced detectable cytotoxic activity. ${ }^{5}$ However, antibodies against cytotoxins have not been reported in convalescent sera, and their role in natural disease remains in doubt. ${ }^{31}$ Our results also indicate the involvement of an active secretory component in fluid accumulation, reflected in bicarbonate concentrations greater than would be expected due to serum leakage alone. Such bicarbonate loss is typical of infectious diarrhoeal diseases such as cholera ${ }^{32}$ however, we obtained no evidence for the involvement of a choleralike enterotoxin in fluid secretion induced by inflammatory strains of $C$. jejuni in this model. This is consistent with previous suggestions that there is no obvious association between toxin production and the type of clinical illness observed..$^{5,31,33}$ Moreover, human volunteer studies indicate that enterotoxin alone cannot explain the clinical features of the inflammatory type of disease observed in developed countries, ${ }^{34}$ and antibodies against enterotoxin have not been reported in convalescent patients. ${ }^{31}$

Therefore, since cholera-like enterotoxin is unlikely to be an important component of the pathogenesis of C. jejuni-induced diarrhoea, we propose instead the 
involvement of host-derived mediators of secretion associated with tissue inflammation, as has been suggested for Salmonella typhimurium and Shigella flexneri. ${ }^{35,36}$ The nature of the host secretory response in $C$. jejuni-induced inflammatory diarrhoea is currently under investigation in our laboratories.

\section{References}

1. Skirrow MB. Campylobacter enteritis: a "new" disease. $B M J$ 1977; 2: 9-11.

2. Butzler JP, Skirrow MB. Campylobacter enteritis. Clin Gastroenterol 1979; 8: 737-765.

3. Fox GJ. Campylobacteriosis - a new disease in laboratory animals. Lab Anim Sci 1982; 32: 625-637.

4. Van Spreeuwel JP, Duursma GC, Meijer CJLM, Bax R, Rosekrans PCM, Lindeman J. Campylobacter colitis: histological immunohistochemical and ultrastructural findings. Gut 1985; 26: 945-951.

5. Everest PH, Goossens H, Butzler JP et al. Differentiated Caco2 cells as a model for enteric invasion by Campylobacter jejuni and C. coli. J Med Microbiol 1992; 37: 319-325.

6. Blaser MJ, Perez-Perez G, Smith PF et al. Extraintestinal Campylobacter jejuni and Campylobacter coli infections: host factors and strain characteristics. J Infect Dis 1986; 153: 552-559.

7. Prescott JF, Barker IK, Manninen KI, Miniats OP. Campylobacter jejuni colitis in gnotobiotic dogs. Can J Comp Med 1981; 45: 377-383.

8. Fitzgeorge RB, Baskerville A, Lander KP. Experimental infection of Rhesus monkeys with a human strain of Campylobacter jejuni. J Hyg 1981; 86: 343-351.

9. Russell RG, Blaser MJ, Sarmiento JI, Fox J. Experimental Campylobacter jejuni infection in Macaca nemestrina. Infect Immun 1989; 57 : 1438-1444.

10. Field LH, Underwood JL, Berry LJ. The role of gut flora and animal passage in the colonization of adult mice with Campylobacter jejuni. J Med Microbiol 1984; 17: 59-66.

11. Blaser MJ, Duncan DJ, Smith PF. Pathogenesis of campylobacter infection: clearance of bacteraemia in mice. Microecol Ther 1984; 14: 103-108.

12. Kazmi SU, Robertson BS, Stern NJ. Animal passed, virulence enhanced Campylobacter jejuni causes enteritis in neonatal mice. Curr Microbiol 1984; 11 : 159-164.

13. Humphrey CD, Montag DM, Pittman FE. Experimental infection of hamsters with Campylobacter jejuni. J Infect Dis $1985 ; 151$ : 485-493.

14. Spira WM, Sack RB, Froehlich JL. Simple adult rabbit model for Vibrio cholerae and enterotoxigenic Escherichia coli diarrhea. Infect Immun 1981; 32: 739-747.

15. Spira WM, Sack RB. Kinetics of early cholera infection in the removable intestinal tie-adult rabbit diarrhea model. Infect Immun 1982; 35: 952-957.

16. Caldwell MB, Walker RI, Stewart SD, Rogers JE. Simple adult rabbit model for Campylobacter jejuni enteritis. Infect Immun 1983; 42: 1176-1182.

17. Williams Smith $\mathrm{H}$, Halls $\mathrm{S}$. Observations by the ligated intestinal segment and oral inoculation methods on Escherichia coli infections in pigs, calves, lambs and rabbits. $J$ Pathol Bacteriol 1967; 93: 499-530.

18. Sedlock DM, Deibel RH. Detection of salmonella enterotoxin using rabbit ileal loops. Can J Microbiol 1978; 24: 268-273.

19. Mitchell TJ, Ketley JM, Haslam SC et al. Effect of toxin A and B of Clostridium difficile on rabbit ileum and colon. Gut 1986; $27: 78-85$.

20. Leitch GJ. Cholera enterotoxin-induced mucus secretion and
We are grateful to S. P. Borriello for providing $C$. jejuni strain NCTC 12189 , and to T. S. Wallis for help with histology. This work was supported by the Commission of the European Communities (H.G., S.K. and P.H.W.), the Royal Society (J.M.K.), the SERC (P.H.E.), the MRC (R.L.) and the Wellcome Trust (D.R.L. and J.M.K.).

increase in the mucus blanket of the rabbit ileum in vivo. Infect Immun 1988; 56: 2871-2875.

21. Wallis TS, Hawker RJH, Candy DCA et al. Quantification of the leucocyte influx into rabbit ileal loops induced by strains of Salmonella typhimurium of different virulence. $J$ Med Microbiol 1989; 30: 149-156.

22. McCardell BA, Madden JM, Bier JW, Lee EC, Dallas HL. In: Pearson AD, Skirrow MB, Rowe B, Davies JR, Jones DM (eds) Campylobacter II. London, Public Health Laboratory Service. 1983: 128

23. Svennerholm AM, Holmgren J. Identification of heat-labile enterotoxin by means of a ganglioside immunosorbent assay (GM1-ELISA) procedure. Curr Microbiol 1978; 1: $19-23$.

24. Abimiku AG, Dolby JM, Borriello SP, Davies H. Protection against gastrointestinal colonization by Campylobacter jejuni in the infant mouse model. Microecol Ther 1989; 18 : 233-239.

25. Bradford MM. A rapid and sensitive method for the quantitation of microgram quantities of protein utilizing the principle of protein-dye binding. Anal Biochem 1976; 72 : 248-254.

26. Miles AA, Misra SS, Irwin JO. The estimation of the bactericidal power of the blood. J Hyg Camb 1938; 38: 732-749.

27. Taylor PW. Measurement of the bactericidal activity of serum. In: Sussman M (ed) The virulence of Escherichia coli. London, Academic Press. 1985: 445-456.

28. Skirrow MB, Jones DM, Sutcliffe E, Benjamin J. Campylobacter bacteraemia in England and Wales: an update. Microb Ecol Health Dis 1991; 4: S3.

29. Blaser MJ, Smith PF, Kohler PF. Susceptibility of Campylobacter isolates to the bactericidal activity of human serum. $J$ Infect Dis 1985; 151 : 227-235.

30. Ketley JM, Mitchell TJ, Candy DCA, Burdon DW, Stephen J. The effects of Clostridium difficile crude toxins and toxin A on ileal and colonic loops in immune and non-immune rabbits. J Med Microbiol 1987; 24: 41-52.

31. Perez-Perez G, Cohn DL, Guerrant RL, Patton CM, Reller LB, Blaser MJ. Clinical and immunological significance of cholera-like toxin and cytotoxin production by Campylobacter species in patients with acute inflammatory diarrhea in the USA. $J$ Infect Dis $1989 ; 160: 460-468$.

32. Field M. Secretion of electrolytes and water by mammalian small intestine. In: Johnson LR (ed) Physiology of the gastrointestinal tract, vol 2. New York, Raven Press. 1981: 963-982.

33. Mathan VI, Rajan DP, Klipstein FA, Engert RF. Enterotoxigenic Campylobacter jejuni among children in South India. Lancet 1984; 2 : 981.

34. Black RE, Levine MM, Clements ML, Hughes TP, Blaser MJ. Experimental Campylobacter jejuni infection in humans. $J$ Infect Dis 1988; 157: 472-479.

35. Gots RE, Formal SB, Giannella RA. Indomethacin inhibition of Salmonella typhimurium, Shigella flexneri, and choleramediated rabbit ileal secretion. $J$ Infect Dis 1974; 130: 280-284.

36. Giannella RA. Importance of the intestinal inflammatory reaction in salmonella-mediated intestinal secretion. Infect Immun 1979; 23: 140-145. 